\title{
New Titles
}

Prepared by Roy John

$\dagger$ Available for review * Assigned

Currency Codes - CAD Canadian Dollars, USD U.S. Dollars, EUR Euros, AUD Australian Dollars.

\section{ZOOLOGY}

* Amphibians of Ohio. Edited by Ralph A. Pfingsten, Jeffrey G. Davis, Timothy O. Matson, Greg Lipps, Jr., Doug Wynn, and Brian J. Armitage. 2013. Ohio Biological Survey, P.O. Box 21370, Columbus, OH, USA, 43221-0370. 916 pages, 90.00 USD, Cloth.

Animal Earth. By Ross Piper. 2013. Thames \& Hudson, 181A High Holborn, London, UK, WC1V 7QX. 320 pages, 45.00 USD, Cloth.

Animals of the Serengeti and Ngorongoro Conservation Area. By Adam Scott Kennedy, and Vicki Kennedy. 2014. Princeton University Press, 41 William Street, Princeton, NJ, USA, 08540-5237. 152 pages, 27.95 USD, Paper.

A Field Guide to the Ants of New England. By Aaron M. Ellison, Elizabeth J. Farnsworth, and Nicholas J. Gotelli. 2012. Yale University Press, P.O. Box 209040, New Haven, CT, USA, 06520-9040. 416 pages, 33.46 CAD, Paper.

Phillipps' Field Guide to the Birds of Borneo, Sabah, Sarawak, Brunei, and Kalimantan (Third Edition, Fully Revised). By Quentin Phillipps, and Karen Phillipps. 2014. Princeton University Press, 41 William Street, Princeton, NJ, USA, 08540-5237. 384 pages, 35.00 USD, Paper.

Birds of Kenya's Rift Valley. By Adam Scott Kennedy. 2014. Princeton University Press, 41 William Street, Princeton, NJ, USA, 08540-5237. 264 pages, 29.95 USD, Paper.

Birds of the Serengeti and Ngorongoro Conservation Area. By Adam Scott Kennedy. 2014. Princeton University Press, 41 William Street, Princeton, NJ, USA, 08540-5237. 224 pages, 27.95 USD, Paper.

Ten Thousand Birds. By Tim Birkhead, Jo Wimpenny, and Bob Montgomerie, 2014. Princeton University Press, 41 William Street, Princeton, NJ, USA, 085405237. 544 pages, 45.00 USD, Cloth.

Beetles of Eastern North America. By Arthur V. Evans. 2014. Princeton University Press, 41 William Street, Princeton, NJ, USA, 08540-5237. 544 pages, 35.00 USD, Paper.

Bumble Bees of North America - An Identification Guide. By Paul H. Williams, Robbin W. Thorp, Leif
L. Richardson, and Sheila R. Colla. 2014. Princeton University Press, 41 William Street, Princeton, NJ, USA, 08540-5237. 208 pages, 24.95 USD, Paper.

The Fauna of British India Including Ceylon and Burma - Butterflies Vol. 1. By G. Talbot. 2013. Today \& Tomorrows Printers and Publishers Karol Bagh, Delhi, India, 110005. xxx +600 pages, 1000.00 INR (about 18.00 CAD).

Wildlife of the Caribbean. By Herbert A. Raffaele, and James W. Wiley. 2014. Princeton University Press, 41 William Street, Princeton, NJ, USA, 08540-5237. 304 pages, 19.95 USD, Paper.

Conus of the Southeastern United States and Caribbean. By Alan J. Kohn. 2014. Princeton University Press, 41 William Street, Princeton, NJ, USA, 085405237. 528 pages, 99.50 USD, Cloth.

* Deer. By John Fletcher. 2014. The University of Chicago Press, 1427 East 60th Street, Chicago, IL, USA, 60637. 207 pages, 16.02 USD, Paper.

$\dagger$ Dolphin. By Alan Rauch. 2014. The University of Chicago Press, 1427 East 60th Street, Chicago, IL, USA, 60637. 207 pages, 16.02 USD, Paper.

Britain's Dragonflies - A Field Guide to the Damselflies and Dragonflies of Britain and Ireland Third Edition. By Dave Smallshire, and Andy Swash. 2014. Princeton University Press, 41 William Street, Princeton, NJ, USA, 08540-5237. 208 pages, 25.95 USD, Paper.

Lost Animals - Extinction and the Photographic Record. By Errol Fuller. 2013. Princeton University Press, 41 William Street, Princeton, NJ, USA, 085405237. 240 pages, 29.95 USD, Cloth.

The Amazing World of Flyingfish. By Steve N. G. Howell. 2014. Princeton University Press, 41 William Street, Princeton, NJ, USA, 08540-5237. 48 pages, 12.95 USD, Cloth.

Life on the Rocks: A Portrait of the American Mountain Goat. By Bruce L. Smith. 2012. University of Colorado Press, University Press of Colorado, 5589 Arapahoe Ave., Suite 206C, Boulder, CO, USA, 80303. 192 pages, 34.95 USD, Cloth. 
A Field Guide to the Larger Mammals of Tanzania. By Charles Foley, Lara Foley, Alex Lobora, Daniela De Luca, Maurus Msuha, Tim R. B. Davenport, and Sarah Durant. 2014. Princeton University Press, 41 William Street, Princeton, NJ, USA, 08540-5237. 320 pages, 29.95 USD, Paper.

* Octopus. By R. Schweid. 2014. The University of Chicago Press, 1427 East 60th Street, Chicago, IL, USA, 60637. 207 pages, 16.02 USD, Paper.

Introduction to Marine Plankton. By Abhijit Mitra, Kakoli Banerjee, and Avijit Gangopadhyay. Daya Publishing House, A Unit of Astral International Pvt Ltd., 81, Darya Ganj, Near Hindi Park, Delhi Medical Association Road, New Delhi, India, 110002. 102 pages, 12.00 USD.

* Rabbit. By V. Dickenson. 2014. The University of Chicago Press, 1427 East 60th Street, Chicago, IL, USA, 60637. 207 pages, 16.02 USD, Paper.

The Extreme Life of the Sea. By Stephen R. Palumbi, and Anthony R. Palumbi. 2014. Princeton University Press, 41 William Street, Princeton, NJ, USA, 085405237. 256 pages, 27.95 USD, Cloth.

* How Snakes Work: Structure, Function and Behaviour of the World's Snakes. By Harvey Lillywhite. 2014. Oxford University Press, 198 Madison Avenue, New York, NY, USA, 10016. 24 pages, 54.05 CAD, Cloth.

A Sparrowhawk's Lament - How British Breeding Birds of Prey Are Faring. By David Cobham, and Bruce Pearson. 2014. Princeton University Press, 41 William Street, Princeton, NJ, USA, 08540-5237. 256 pages, 35.00 USD, Cloth.

\section{BOTANY}

* Braiding Sweetgrass: Indigenous Wisdom, Scientific Knowledge, and the Teachings of Plants. By Robin Wall Kimmerer. 2013. Milkweed Editions, 1635 West 12th Avenue, Vancouver, Canada, V6J 2E3. 320 pages, 24.00 CAD.
Trees of Western North America. By Richard Spellenberg, Christopher J. Earle, and Gil Nelson 2014. Princeton University Press, 41 William Street, Princeton, NJ, USA, 08540-5237. 448 pages, 29.95 USD, Paper, 60.00 USD, Cloth.

Trees of Eastern North America. By Gil Nelson, Christopher J. Earle, and Richard Spellenberg. 2014. Princeton University Press, 41 William Street, Princeton, NJ, USA, 08540-5237. 656 pages, 29.95 USD, Paper, 65.00 USD, Cloth.

\section{OTHER}

* Tracks and Shadows: Field Biology as Art. By W. Harry. 2013. University of California Press, 1445 Lower Ferry Road, Ewing, NJ, USA, 08618. 296 pages, 29.95 USD, Cloth.

* A Love Affair with Birds: The Life of Thomas Sadler Roberts. By Sue Leaf. 2013. University of Minnesota Press, Suite 290111 Third Avenue South, Minneapolis, MN, USA, 55401. 29.95 USD.

* The dismal state of the Great Lakes. By James Pinson Ludwig, 2013. Xlibris LLC, 1663 Liberty Drive, Suite 200, Bloomington, IN, USA, 47403. 273 pages, 20.95 USD.

Marine Community Ecology and Conservation. By Mark D. Bertness, John F. Bruno, Brian R. Silliman, and John J. Stachowiczi. 2013. Sinauer Associates, Inc., 23 Plumtree Road, P.O. Box 407, Sunderland, MA, USA, 01375-0407. 675 pages, 109.95 USD, Cloth.

* On the Organic Law of Change - A Facsimile Edition and Annotated Transcription of Alfred Russel Wallace's Species Notebook of 1855-1859. By Alfred Russel Wallace. (Introduction and notes by James T. Costa). 2013. Harvard University Press, 79 Garden Street, Cambridge, MA, USA, 02138. 592 pages, 49.95 USD, Cloth. 